\title{
TÜRK HUKUKUNDA MECRALAR
}

Yazan : Asistan Dr. Halûk Tandoğan

\author{
A. UMUMTYETLE MECRALAR \\ I. MECRALARIN EHEMMTYETI VE BUNLAR HAKKINDA \\ MEDENÎ KANUNA VE DİĞER BAZI KANUNLARA HUSUSÎ \\ HUKUMLER KONULMASININ SEBEPLERI
}

Memleketimizin tabiî kuvvetlerinden istifade ve sanayiinm geliştirilmesi yolunda her geçen gün yeni adımlar atılmaktadır. Millî istihsalimizin artması ve halkımızın daha yüksek bir yaşama seviyesine ulaştırılması ancak, su, elektrik, gaz gibi madde ve kuvvetlerden lâyıkı veçhile faydalanmak suretile mümkündür. Bu itibarla bu madde ve kuvvetlerin nakil ve tevziini temin eden mecraların ekonomik ve sosyal ehemmiyeti büyüktür.

Mahiyetleri icabı, ekseriya mecraları, kendisinden çıktıkları sınâ̂ teşebbüsün ve onlardan faydalananların maliki olmadıkları gayri menkullerden geçirmek zarureti karşısında kalınmaktadır. Gayrimenkul malikleri çok defa, kendi arazilerinde başkasının mecra tesis etmesine riza göstermemektedirler. Filhakika bu tesis ameliyesi gayrimenkul üzerinde bir takım çalışmaları icap ettirdiği gibi mecraların sadece mevcudiyeti ve onlarm bakım ve kontrolüne tahammül dahi malikin mülkünden istifadesini takyid etmektedir. Mecralarmn naklettikleri kuvvet ve maddeler dolayısiyle bazı tehlikeler arzetmeleri de onların tesisine müsaade verilmemesinde âmil olmaktadır. Bundan başka, mecra tesis etmek zaruretinde olanlarm bu hallerini istismar etmek isteyen arazi sahiplerine de rastlanmaktadır: Hele tesisatı, bir şehrin elektrik şebekesi için bahis mevzuu olduğu gibi, çok sayıda gayrimenkulden geçirmek icap ediyorsa karşılaşılan güçülükler o nisbette aramaktadır. Işte kanun vazı saydığımız güçlïkleri gözönüne alarak (1) bir taraftan umumî menfaatı ilgilendiren mecraları kuran teșebbüs ve müesseselere hususî kanunlarla istimlâk selâhiyeti bahşettmiş diğer taraftan MK m. 668 vasıtasiy-

(1) Erhard Romer : Die Behandlung der Leitungen nach schweizerischem Zivilrecht, ZSR, N. F. 65 (1946), sh. 64-65; Robert Haab : Kommentar zum schweizerischen Zivilgesetzbuch, IV. Band - I. Teil, Das Sachenrecht, Zürich 1933, Art, 691 - 693, Nr. 1 
le de komşuluk münasebetlerine müstenid zarurî mesra hakkını tanımiștur.

Mecraların başkasının gayrimenkulünü katetmesi zarureti eşya hukukunun umumî prensipleri muvacehesinde de şu meseleyi ortaya çıkarmıstır: Gayrimenkul mülkiyeti, kaideten, devamlı ve sıkı surette arza bağlı bulunan bütün şeylere şamildir (MK. m. 619 ve 644). Binaenaleyh mecraların mülkiyetinin de üzerinde tesis eddildik!eri gayrimenkulün malikine ait olması lâzım gelirdi. Bu takdirde, teşebbüsün bir bașkasına devri veya rehni halinde mecraların da birlikte intikali veya teminat gösterilmesi mümkün olamayacaktı. Halbuki teşebbüs mevcudunun büyük bir kısmını bunların konulmasına tahsis etmiş bulunmaktadır. Teşebbüs sabihinin mecralar üzerinde tasarruf edebilmesi ancak bunların katettiği her gayrimenkulde müstakil ve daimî bir inşaat hakkı tełsisi ve bu suretle tesis edilen hakların gayrimenkul olarak tapu siciline kayıtları ile kabil olacaktı; yahut da teşebbüsün mecraların işgal ettiği gayrimenkul parçalarını satın alması gerekecekti. Her iki yol ise aşırı masraflar yapilmasina sebebiyet verecekti. Bu mahzurları önlemek maksadiyle (2) MK, mecraları kendisinden inbias ettikleri teşebbüsün teferruatı ve onun sahibinin mülkü saymaktadır (m. 653 f. I).

Geniş ölçüde mecra tesis elden teşebbüslerin mecraların geçirmek için elde ettikleri irtifak haklarının, umumî hükümlere binaen, tapu sicilinde hâdim gayrimenkullere ait sahifelere ayrı ayrı tescili de bu teşebbüslerin masraflarını ehemmiyetli derecede arttıracaktı. Bu masrafları bertaraf etmeyi arzu eden kanun vazı, açıkta bulunan mecraların kâfi derecede aleniyeti haiz olduklarını göz önünde tutarak onlara müteallik irtifak haklarını tescilden muaf kılmıştır (MK. m. 653 f. III) (3).

\section{BAŞKASININ GAYRIMENKULU UZERINDE BIR MECRA TESISI IÇIN HUKUKÎ IMKÂNLAR.}

Başkasının gayrimenkulü üzerinde bir mecra tesisi ya bir hususî hukuk muamelesine ya bir idarî tasarrufa yahut da bir kanun hükmüne müsteniden mümkündür.

(2) Romer, a. g. e., sh. 65; Haab, Komm., Art. 676, Nr. 12; Hans Leemann; Kommentar zum schweizerischen Zivilgesetzbuch, Band IV, Sachenrecht, I. Abteilung, Bern 1920, Art. 676. Nr. I;Pfleghart: Das Recht zur Erstellung elektrischer Leitungen nach der schweizerischen Bundesgesetzgebung (de lege lata und de lege ferenda), ZSR, N. F. 23 (1904), sh. 81-84; E. Hirş : Ticaret Hukuku Dersleri, 2. bası, İstanbul 1946, sh. 55; Karl Bruggmann: Das Durchleitungsrecht im schweizerischen Privatrecht, Diss. Bern 1913, sh. $79-81$.

(3) C. Wieland : Aynî Haklar, terc. eden İ. Hakkı Karafakı, Ankara 1946, m. 676 (653), no. 1; Hirş; a. g. e., sh. 55 


\section{Bir hususî hukuk muamelesine müsteniden mecra tesisi.}

Hususî şahıslara ait gayrimenkullerden bir mecra geçirmek iç:n en basit ve normal yol bu şahıslarla bir akit yapmaktır. Böylece gayrimenkul malikiyle sulhan anlaşmak, onu, komşuluk münasebetlerini ileri sürerek veya istimlâke başvurarak, mecranın konulmasıına tahammüil hususunda icbar etmeğe tetrcih edilmelidir. Bu suretle her iki tarafın menfaatler:ni daha iyi nazara almak ve istimlâke gidildiği takdirde yapllacak masrafları önlemek mümkündür (4).

Mecra tesisini tazammun eden hukukî muamelenin muhtevası muhtelif olabilir:

a) Gayrimenkul maliki mecranm tesisine muvakkat olmak üzere müsaade edebilir. Bu müsaade mecra kuran. lehine bir sübjektif hak doğurmaz; gayrimenkul maliki müsaadesini her zaman geri alabilir. Böyle bir müsaade taraflar arasında sadece fiilî bir münasebete vücut vermekle kalmayıp hukukî bakımdan da ehemmiyet taşır: mecranın gayrimenkul üzerine yerleştirilmesi, müsaade baki kaldıkça, haksız bir müdahale saylamaz (5).

b) Mecranın tesisi için şahsî bir hak, bir alacak hakkı doğuran bir akit te yapmak mümkündür (6). Bu hak borçlu olan gayrimenkul malikine ve onun mirasçılarına karşı dermeyan edilebilir. Fakat malikin yap̣tığı mukavele gayrimenkulü sonradan iktisap eden üçüncü şahıslar, bağlamaz.

c) Akitle, gayrimenkulün sonraki maliklerine det mecrayia tahammül mükellefiyetini yükleyecek bir irtifak hakkı tesisi, umum:yetle uzun zaman için yerleştirilen mecraların hukukî vaziyetindeki istikran sağlamak bakımından en emin yoldur. Bu irtifak hakkının doğumundan, mahiyetinden ve tabi olduğu hükümlerden daha aşağıda teferruatıyla bahsolunacaktır (7).

\section{Idarî bir tasarrufa müsteniden mecra tesisi.}

Umumun istimâl ve istifadesine mahsus àmme emlâkine dahil oian : ayrimenkuler ïrerinde mecra tesisi, bo huasta br kanun hükmïne istinad edilemediği takdirde (8), ancak bir idarî tasarrufla müm-

(4) Romer, a. g. e., sh. 66; Bruggmann, a. g. e., sh. 78.

(5) Haab, Komm., Art. 676, Nr. 2

(6) Haab, Komm., Art. 676, Nr. 3

(7) Bk. aşağıda No. IV.

(8) Bk. aşağıda not 19 ve 20 
kündür (9). Bu gibi idarî tasarruflar mahiyetleri itibariyle üç guruba ayrilirlar:

a) Salâhiyetli idarî merci hususî müessese ve menfaatler lehine, umumî yol ve meydanlar gibi gayrimenkullerden mecra geçirilmesi için bu gayrimenkullerin muvakkaten işgaline tek taraflı olarak izin ve ruhsat verebilir (10). Böylece idarenin muvakkat işgale müsaade etmesi neticesinde mecra tesis eden lehine bir sübjektif hak vücut bulmaz. Muvakkat işgaller, âmme emlâk:nin istimal ve tahsisi c:hetine uygun istifadeler olmadıklarından, bunlara ruhsat verilmesi ferdì hürriyetler ve âmme hakları ileri sürülerek istenemez. Ruhsatın bahşedilmesi tamamıla idarenin takdirine bağlı olup verilmiş olan izin de daima geri alınabilir. Bununla beraber muvakkat işgal taleplerinin kanunî bir sebep olmadıkça veya âmme menfaatleri ve hizmetleri, âmme emlâkinin vaziyeti icap ettirmed:kçe kẹfî̀ olarak reddedilmemesi lâzımdır.

b) Salâhiyetli idarî merci ile muayyen müddetli bir mukavele yaparak da âmme emlâki üzerinde mecra tes:sine müsaade istihsâl olunabilir (11). Bu takdirdee mecra tesis eden lehine muvakkat işgal için bir sübjektif hak doğar (12). Bununla beraber ferdin istifadesi için bir müddetin tayin edilmiş olması akit neticesinde verilen ruhsatm geri alımasına mani değildir. Yalnız tayin edilen müddetin hitamından evvel idarece işgale nihayet verilmişse mecra sahibi bir tazminat istiyebilir.

c) Elektrik, su, havagazı gibi âmme hizmeti imtiyazları da imtiyaz sahibine imtiyaz devam ettiği müddetçe âmme emlâkini işgal etmek ve üzerinde tesisat vücuda getirmek salâhiyetini bahşeder (13).

Muvakkat işgal ve imtiyaz neticesinde mecra kuran lehine doğan hak bir idarî aynî hak olarak vasıflandırılmaktadır (14). Bu hak medenî

(9) Haab, Komm., Art, 676, Nr. 4; Srddık Sami Onar: İdare Hukukunun Umumî Esasları, İstanbul 1952, sh. 950 ve müt.; Süheyp Derbil : İdare Hukuku, cilt I, Ankara 1940, sh. 417 ve müt.

(10) Onar, a. g. e., sh. 950 - 951; Derbil, a. g. e., sh. $417-420$.

(11) Onar, a. g. e., sh. 951; Derbil, a. g. e., sh. $420-421$.

(12) Böylece fert lehine sübjektif bir hak doğuran muvakkat işgal müsaadesi geniş manada imtiyaz mefhumuna girer: Onar, a. g. e., sh. 952

(13) Onar, a. g. e., sh. 952; Derbil. a. g. e., sh. 423 - 424; ayni müellif, Idare Hukuku, cilt II, Ankara 1952, sh. 570. Ankara'da elektrik tesisatı vücuda getirme ve işletme imtiyazı mukavelesi, m. 1 (20 Mart 1926; 3. Ter. Düstur, cilt 8, sh. 308); Ankara'da havagazı tesisatı vücuda getirme ve işletme imtiyazı mukavelesi, m. 1 (20 Mart 1926, 3. Ter. Düstur, cilt 8. sh. 327)

(14) Onar, a.g. e., sh. 953. Haab, Komm., Art. 664, Nr. 23 le karşılaştırınix. 
hukuktaki mecra irtifak hakkından muhtelif bakımlardan ayrilır (15): İdare, alelâde bir malikten farklı olarak, zabita salâhiyetlerine ve âmme emlâk:nin idaresi hususundaki vazifelerine dayanarak idarî aynî hak sahibine karşı hareket ve onun hakkını kullanma tarzma müdahale edebilir. Diğer taraftan medenî hukuktaki mecra irtifak hakkı daimî veya muayyen bir müddetle mukayyet olduğu halde, idarî mecra hakkı daima muvakkat bir mahiyet arzeder. Hiç bir zaman daimî olamayacağı gibi devamı için bir müddet tayin edilmiş olsa bile her zaman geri alınması mümkündür. Bundan başka idarî mecra hakkı, taallûk ettiği âmme emlâkinin mahiyetini ve hatta tahsis ve istimal cihetini muhafaza etmesiyle kaimdir. Bu mahiyette ve cihette vaki değişmeler o mülk üzerinde tesis edilmiş idarì aynî haklara da tesir eder ve varlıklarına son verir. Nihayet, bir âmine imtiyazı dolayısıyla tesis edilen mecra hakkı idareye ve âmmeye karşı takabbül edilen bir vazifenin ifasını temin için tanınır, halbuki medenî hukuktaki mecra hakkı hak sahibi lehine olarak tesis edilir.

\section{Bir kanun hükmüne müsteniden mecra tesisi.}

Mecra tesisi hakkı ve mecraya tahammül mükellefiyeti gayrimenkul mülkiyetini takyid eden bir kanun hükmünden doğabileceği gibi muhtelif kanunî hükümler umumun menfaati icap ettird:ği hallerde istimlâk yoluyla (15a) mecra tesisine imkân vermektedir. Bu hususta şu tefrikler yapulabilir:

a) Medenî Kanun'un 668 inci maddesi komşuluk münasebetlerinden doğan gayrimenkul mülkiyeti takyidlerinden birini ihtiva etmektedir. Mezkûr madde mucibince gayrimenkul maliki muayyen şartlarm tahakkuku halinde arazisi üzerinden komşusunun bir mecra geçirmesine tahammül etmekle mükelleftir. Bu tahammül mükellefiyeti, ileride yazımızın B. kısmında etraflıca tetkik olunacaktır.

b) Âmmenin menfaati için vazedilmiş bir mülkiyet takyidine binaen de hususî şahıslarm mülkleri üzerinde bir mecra tesis edilebilir.

Böyle bir takyidin bir misali 4 Şubat 1340 tarihli ve 406 saylı -Telgraf ve Telefon Kanunusnun 14 üncü maddesinde bulunmaktadır. Bu maddeye göre: aHükûmet eşhasın tahtı tasarrufundaki arazinin

(15) Onar, a.g.e., sh. 953

(15 a) İstimlâk da esas itibariyle bir idarî tasarrufu tazammun etmekle beraber, kanunî mülkiyet takyidleriyle olan yakın alâkası ve bazı benzerlikleri dolayısıyla, ondan da bu kisimda bahsetmekteyiz. 
dahilinde ve emlâk ve müessesatin haricinde telgraf ve telefon tesisatı inşasına salâhiyettardır. Ancak yapılacak tesisat işbu arazi, emlâk ve müessesatın istimal ve istifadesini haleldar etmemesi lâzımdır.»

P. T. T. Idaresinin hususî şahısların gayrimenkullerini kateden tesisat kurma salàhiyeti MK. m. 657 mucibince tapu siciline tescile hacet olmaksızın doğar. Tesisatın konulması idarî bir tasarruf olup gayrimenkul malkiyle bir irtifak hakkı tesisinde olduğu gibi önceden resmî bir mukavelenin yapılması gerekmez (16). Tesisatın mevcudiyeti tapu sicilinde gayrimenkulün evsafına müteallik haneyeł şerh verilebilir (17). Eğer tesisat kurulduğu gayrimenkulün istimâl ve ist fadesini ehemmiyetli surette haleldar ediyorsa MK. m. 669 cümle II deki esastan ilham alınarak arazinin istimlâki cihetine gidilmelidir (18).

406 sayılı Kanun'un 12 inci maddesi de P. T. T. Idaresine "kendi nâkil ve kablolarının tesis ve vaz'ı için umuma ait arazi ve tarikleri işbu arazi vel turuk üzerinde mürur ve ubura sureti daimede halel gelmemek üzere istimal etmek» hakkını tanımaktadır (19).

Halen meriyetten kalkmış olan 28 Mayıs 1927 tarih ve 1055 sayılı "Teşviki Sanayi Kanunu Muvakkatı»nn 6 mcl maddesine göre, bu kanundan istifade hakkını haiz olan sınaî müesseseler kuvvei muharrikeler:ni nakleden hatları ve hususî telgraf ve telefon hatlarmı umumî yolların kenarlarıyla devlete ait araziden meccanen geçirebiliyorlardı (20). Ayni madde bu hatları hususî şahıslara ait araziden, sahiplerine Ticaret Vekâletince takdir olunacak muhik bir tazminat itası suretiyle, geçirmeğe, bunlar için direk rekzetmeğe ve icab ettikçe tamirlerine müsaade ediyordu. Burada da mecra tesisi kanunî bir mülkyet takyidine istinad etmekteydi ve tapu sicilinde tescile lüzum olmadan yaprlabilmesi lâzım gelmekteydi.

c) Üzerlerinden mecra geçirilecek gayrimenkullerin maliklerinin çok defa bu hususta rıza göstermediklerine yukarıda işaret etmiştik. Bu yüzden umumun menfaati için mecra tesisine girişen teşebbüs ve mües-

(16) Ayni fikirde: Wiederkehr : Die Rechtsstellung der schweiz. Telegraphen - und Telephonenanstalt, Diss. Zürich 1924, sh. 41 ve müt; aksi fikirde: Haab, Komm., Art. 676, Nr. 8.

(17) İsviçre Medenî Kanunu'nun bize intikal etmemiş olan 962 inci maddesi kantonlara âmme hukukundan neşet eden mülkiyet takyidlerinin tapu siciline şerhini emretmek salâhiyetini tanımaktadır. Bk. Haab, Komm., Art. 680, Nr. 3.

(18) Karşılaştırınız : Haab, Komm., Art. 667, Nr. 8

(19) Bk, yukarida not 8

(20) Bk. yukarıda not 8 
seselere, muhtelif hususî kanunlarla, mecraların geçirecekleri gayrimenkulleri istimlâk salâhiyeti tanımış bulunmaktadır. Bu kanunlardan bilhassa mevzuumuzu ilgilendirenleri şunlardır (21):

24 Teşrinisani 1295 tarihli «Menafii umumiye için istimlâk kararnamesi» mecralar için yapılacak istimlâkin en başta gelen mesnedini teşkil eder. Bu Kararname'nin, 17 Nisan 1330 tarihli Kanun'la muaddel, 1 inci maddesi umumî menfaatlerin neler olabileceği hususunda verdiği misaller arasinda su yolları tanzimini de saymaktadır. Elektrik ve gaz mecralarını da su yollarına kıyaslamak mümkündür.

-Menafii umumiyeye müteallik imtiyazat» hakkındaki 10 Haziran 1326 tarihli Kanun'un 2 nci maddesi bu gibi imtiyaz sahiplerine «imtiyazı itâ olunacak imalât ve müteferriatının tesisine muktazi» araziyi bu arazi eshabı ile onun satılması hususunda itilâf hasıl olmadığı takdirde Ístimlâk Kararname’sine tevfikan iştira salâhiyeti bahşetmektedir. Nitekim 1326 tarihli Kanun'dan sonra verilen muhtelif elektrik ve havagazı tesisatı vücuda getirme ve işletme imtiyazlarında ona atıflar bulunmaktadır (22).

1055 sayılı Teşviki Sanayi Kanunu'nun 4 üncü maddesine göre, bu kanundan istifade hakkını haiz olan sınaî müesseseler kuvvei muharrikelerinin istihsal ve nakline yarayan tesisat için muktazi araziyi istimlâk salâhiyetine de sahip bulunuyorlardı.

18 Ocak 1950 tarih ve 5516 sayll «Bataklikların kurutulması ve bunlardan elde edilecek topraklar hakkında Kanun'un 10 uncu maddesine binaen kurutma için gerekli mecraların tesisi zımnında kurutma dışında kalan; eşhasa ait arazi istimlâk edilebilir.

14 Temmuz 1939 tarih ve 3710 saylı «Belediye İstimlâkk Kanunu'nun 1 inci maddesi Belediye Kanununda yazıli, beldenin ve belde sakinlerinin medenî, sıhhî ve bediî ihtiyaçlarının tanzim ve tesviyesi ... için tesisat yapmak maksadıyla binalı ve binasız gayrimenkulleri... istimlâke. belediyeleri salâhiyetli kılmaktadır. Su, elektrik, havagazı tesisatı kurulması beldenin ve belde sakinlerin:n en mühim ihtiyaçlarından olup belediye sınırı içinde bu tesisatı kurmak hakkı 3 Nisan 1930 tarih ve 1580

(21) İstimlâke ait teferruat için bk: Mukbil Özyörük : Kamulaştırma Hukuku, Ankara 1948.

(22) Dersaadetin Rumeli cihetiyle mülhakatında telgraf ve telefon ile kudreti elektrikiyenin tevzii hakkında imtiyaz mukavelesi, m. 7 (11 Teşrinievvel 1326, 2. Ter. Düstur, cilt 2. sh. 755); 20 Mart 1926 tarihli Ankara'da elektrik ve havagazı tesisatı vücuda getirme ve işletme imtiyazlarının 17 nci maddeleri. 
sayll Belediye Kanunu'nun 19 uncu maddesinin 4 A bendi mucibince belediyelere veya onlardan imtiyaz olan müessesata verilmiştir (23). Belediyeler, 3710 sayll Kanunun 1 inci maddesin n 2 inci fikrasina binaen, lüzum görürlerse belde dişından getirilecek suların kaynaktan beldeye kadar geçeceği yerleri dahi istimlâk edebilirler.

Bütün bu saydığımız hükümler mucibince yapılan istimlâklerin mevzuunu gayrimenkuller teşkil etmektedir. Başka bir deyimle, bu hükümler mecranın katedeceği gayrirnenkullerin mülkiyetinin, muayyen bir bedel mukabilinde ve sahiplerinin ruzasına bakılmaksızın, mecra kurana intikalini istihdaf etmektedirler (24). Halbuki Isviçrede istimlâk yoluyla, mecra kuran teşebbüs veya müessese lehine, başkasının arazisi üzerinde bir irtifak hakkı tesis edilebileceği umumiyetle kabul edilmektedir (25). Yani bu takdirde istimlákin mevzuunu mülkiyetin intikali değil sadece mecra irtifak hakkmın tesisi teşkil etmektedir. Bir mecra geçirmek için gayrimenkulün bir kısmmı veya tamamını istimlâk etmek mecra kuran teşebüs için büyük külfetleri mucip olmaktadır. Bu itibarla biran evvel yapılması temenni edilen (26) yeni umumî mahiyette bir istimlâk kanununda istimlâk yoluyla bir irtifak hakkının tesis edilebileceği hususunun da kabulü yerinde olur.

\section{MEDENÎ KANUN'A GÖRE MECRA MEFHUMU VE NEVILERI}

\section{Medenî Kanun'a göre mecra mefhumu}

Medenî Kanun mecraları tarif eden bir hüküm ihtiva etmemektedir. Kanunun 653 üncü maddesinde «elektrik, gaz, su gibi şeylerin mecralar1»ndan, 668 inci maddesinde de «su yolu ve gaz ve elektrik boruları geçirilmesi» nden bahsolunmaktadır. Umumî konuşma dilinde mecralar "kuvvet ve maddelerin nakil ve tevzine yarayan teknik tesisat» olarak tarif edilmektedir (27). Medenî Kanun'a göre mecra mefhumunu tayin için bu tarife sstinad edilebilir. Ancak bu tarifin şümulüne giren tesisa-

(23) 16 Ocak 1942 T. 4325 sayıl «Ankara Elektrik ve Havagazı ve Adana Elektrik Müesseselerinin idare ve işletmeleri hakkındaki Kanun»un 20 nci maddesine göre "işletme icap ve zaruretleri dolayısıyla alınması lâzım gelecek gayrimenkuller Belediye İstimlâk Kanunu hükümlerine göre alınır.»

(24) Bk. Özyörïk, a.g.e. sh. 125 - 132; Onar, a.g.e. sh. 1096 - 1099 Derbil, a.g.e. cilt II, sh. $521-523$.

(25) Robert Haab'jun.: Das Objekt der Expropriation, Diss Bern 1916, sh. 74 ve 77; Haab, Komm. Art. 676, Nr. 8, Art. 691 - 693, Nr. 1; Hans Leemann: Kommentar zum schweizerischen Zivilgesetzbuch, Band IV, Das Sachenrecht, II. Abteilung, Bern 1925, Art, 731, Nr. 11; Wieland. a.g.e. m. 731 (704), no. 3 a. (26) Özyörük, a.g.e. sh. $230-231$ 
tın nelerden ibaret olduğunu ve Medenî Kanun’un 653 ve 668 inci mad. delerinin tatbik sahasm tesbit hususunda doktrinde ve mahkeme içtihatlarında bir takım görüş ayrllıklarma rastlanmaktadır:

a) Bazı müelliflere göre (28) 653 ve 668 inci maddelerdeki mecra mefhumunu geniş mànata almali ve bu hükümleri yalnız su, clektrik ve gaz mecralarma ve bunlara benzer mecralara değil ayni zamanda birden fazla gayrimenkule sirayet eden diğer tesisata da teşmil etmelidir. Filhakika mezkûr maddelerde kullanılan "gibi» tabiri kanundaki tâdadın tahdidî olmadığını göstermektedir (29). Bundan maada bu maddelerin kabulünde âmil olan mülâhazalar birden fazla gayrimenkulü takyid eden ve şeylerin nakline hizmet eden diğer tesisat için de varittir. Bu itibarla 653 ve 668 inci maddelerde zikredilmiş bulunan kaideler teleferikler (30), fünikülerler, bir smaì teşebbüsün kurduğu dekovil hatları, böyle bir teșebbüsü demiryoluna bağlayan hususî hatlar, kurutma ve sulama için yapılan bentler, su kemerleri, üstü açı büyük kanallar hakkında da muteber olmalıdir.

b) Diğer bazı müellifler ve İsviçre Federal Mahkemesi mecra mefhumunun bu kadar geniş mânada tefsir olunmasmı tenkid etmektedirler.

Charles Knapp'n fikrince (31) «mahiyeti ne olursa olsun bir takım mallarn naklini mümkün klan bütün vasitalar mecra değildir. 691 nci madde (TMK. m. 658) dkkatle okunursa görülür ki zarurî mecralar ancak mayilerin, gazlarm ve sureti mahsusada yapılmış kanalların içinde, tabir caizse, kayan diğer akıcı seylerin nakline yarayan tesisattır. Filhakika bu nakil keyfiyeti tamam:yle sabit inşaatın gövdesi içinden geçen bir cereyan şeklinde tezehür eder. Bu gövdenin hiç bir kısmı oynamaz. Buna mukabil sulp olan her cismin nakli umumiyetle, sabit tesisatın göv-

(27) Romer, a. g. ‥, sh. 69; Haab, Komm., Art. 676, Nr. 1; Wieland, a. g. e., m. 676 (653), no. 8; Bruggmann. a. g. e., sh. I; Zahit Imre: Kaynak - yeraltı sulan ve hukukî durumları, İstanbul 1951, sh. 127

(28) Haab, Komm., Art. 676, Nr. 1 ve Art. 691-693, Nr. 9; Leemann, Komm., Art. 676, Nr. 3 ve Art. 691, Nr. 4; Homberger et Martis Propriété fonciére, Rapports de voisinage, FJS, no. 429, sh. 5; Türk hukukçularından Zahit İmre (a. g. e., sh. 126-127) bu müelliflerin fikrine iștiâk eder görünmektedir.

(29) Türk Kanunu Medenî'sinde "gibi» tabiri yalnız 653 üncü maddede mevcut olup 668 inci maddenin ash olan İsviçre Medenî Kanunu'nun 691 inci maddesindeki "benzeri borular» ("..... Gasröhren und dergleichen», *... tuyaux de gaz et autres») tabiri tercüme edilmemiş bulunmaktadır.

(30) Luzern Kantonu Hükûmet şuras» teleferikleri mecra addetmektedir SJZ, 26 (1929/30), sh. 328. no. 227.

(31) Note de jurisprudence, Jd T, 1945, pp. 519 - 521 
desi haricinde ve seyyar bir takım aletler vasitasiyle yapilan bir hareketi, mihanikî bir yer doğiștirmeyi tazammun eder.s Bu sebeple, Knapp, teleferiklerin, fünikülerlerin ve smaî teşebbüslere ait hususî dekovil ve bağlama hatlarının m cralar hakkmdaki hükümlere tabi tutulamıacağını beyan etmektedir. Bununla beraber sulp cisimlerin nakline hizmet eden tesisatın mecra saylamıyacağı hususunda vazettiği kaideye şu istisnayı tanımaktadır: Eğer sulp cisimlerin nakli sabit olan tesisatın gövdesi içinde cereyan ediyorsa bu, mayi ve gazların ve cereyan eden kuvvetlerin nakline kıyasłanabilir. Katı şeylerin bir takım borular içinde havayla birlikte çekild: ği hallerde (pnömatik postalarda olduğu gibi) vaziyet böylet olup bir mecranın mevcudiyetinden bahsedilebilir (32).

Federal Mahkeme de bir teleferiğin IMK. m. 691 in kasdettiği manada bir mecra olmadığına aşağıdaki mucip sebeplerle hükmetmiştir (33): «Kanun tarafından gözönünde tutulan mecraların farik vasfı şudur ki hâdim gayrimenkulün maliki sadece bunların başkasının menfaatine kendi arazisi üstünde sabit bir şekilde kurulmasına katlanmakla mükelleftir; fakat bir kere mecralar yerleștirildi mi artık o bunlarm işlemesinden rahatsız olmaz. Halbuki daimi surette insanların ve şeylerin naklini sağlaması gereken bir teleferik için vaziyet tamamen başkadır. Böyle bir halde, araz:si katedilen maliki rahatsız eden bizzat tesisatın kurulması değil, fakat işletilmesi, yani bir kabloya bağlı vagonun gidip gelmesidir. Bu esaslı fark vakıaya 691 inci maddenin tatb:kini bertaraf eder.s

Bruggmann (34) ve Romer (35) de mecra mefhumunun lüzumundan fazla genişletilmesine muhaliftirler. Bú mïelliflere göre 653 ve 668 inci maddeler ancak, hâdim gayrimenkulden istifadeyi, mezkûr hükümlerde sayılan mecralara benzer bir şekilde, takyid eden tesisata tatbik olunabilir. Hâdim gayrimenkul malikinin daha aşırı bir mükellefiyet altına girmesini icab ettiren su bentleri, eklüzler, üzeri açık büyük kanallar, dekovil hatları gibi tesisat için MK. m. 653 ve 668 de mevzu esaslardan istifade edilememel:dir.

c) Mecra mefhumunun dar tutulması hususunda b) şıkkında arzedilen fikirler essas itibariyle yerindedir. MK. m. 668 e müsteniden, hâdim gayrimenkul malikinin, kendisini bu maddede saylan mecralardan daha

(32) Ayni fikirde : Romer, a. g. e., sh. 69.

(33) RO 71 Il 83 yahut Jd T. 1945, pp. $517-518$, *Hanggi c. Groth»

(34) A. g. e., sh. $55-56$.

(35) A. g. e., sh. $69-70$. 
ziyade rahatsız edecek mahiyette, tesisatın kurulmasına tahammül göstermeğe zorlanması bu hükmün vaz'ıyla güdülen maksadı aşar (36). Su bentleri, eklüzler, teleferik, füniküler, dekovil hatları ve hususî bağlama hatları gibi tesisatın birer mecra olmadiklanı aş:kârdır. Su bentleri ve eklüzler müstesna diğerlerinin icabında lüzumlu geçit hakkındaki MK. m. 671 e binaen tesis edilmeleri mümkündür (37). Ancak bütün bu nevi tesisat birden fazla gayrimenkulü takyid ettikleri takdirde bunlara, kıyas yoluyla, MK. m. 653 hükmünün tatbik edilmesine hiç bir mani yoktur (38). Filhakika bu gibi tesisatın da kendisinden inbias ettikleri teşebbüsün teferruatı addedilmesi ve açıkta oldukları takdirde bunlara müteallik irtifak hakkının tescile tabi tutulmaması sınâ̂ tẹşebbüslerin ihtiyaçlarına tamamen uygundur. Kaldı ki tesisatın üzerinde kurulduğu gayrimenkulün malikinin meşru menfaatleri de 653 üncü maddenin tatbiki dolayısiyle herhangi bir suretle haleldar olmaz (MK. m. 668 in bu tesisatın kurulması için dermeyan edilemeyeceğini kaḅul ettiğimize göre).

\section{Medenî Kanun'a göre mecraların nevileri}

a) Medenî Kanun'un saydığı başlıca mecra nevileri su gaz ve elektrik mecralarıdır. Bu tasnif macraların nakline yaradıkları madde ve kuvvetlerin mahiyeti nazara alınarak yapılmaktadır.

aa) Su mecraları (39): Bunlar muhtelif maksatlara hizmet için tesis eldilmiş olabilirler. Bu arada kurutma veya sulama, bir çeşmenin beslenmesi, su ile işleyen makinelerin veya bir su değirmeninin ihtiyacı olan suyun getirilmesi, içme suyu temini, kirli suların, çirkef sularının akması (40) için kurulan mecralar ve lâğım borularını (41) zikredebiliriz. Bu mecralar maden, taş, toprak gibi muhtelif maddelerden yapılmış ola-

(36) Türk Medenî Kanunu'nun 668 inci maddesinin metni de İsviçre Medenî Kanununun 691 inci maddesinden farklı olarak "benzeri borular» tabirini ihtiva etmediğinden (bk. yukarıda not 29) bu tefsir tarzına daha uygundur. Bk. C. A. Gücün : Nazarî ve amelî hukuk davaları, I. Kitap, İstanbul 1944, sh. 171 ve 200.

(37) Knapp, a.g. e., sh. 520 - 521; Federal Mahkeme de teleferik tesisi için lüzumlu geçit hakkındaki m. 694 e (IMK) müracaatın mümkün olduğunu esas itibariyle kabul etmektedir : Jd T, 1945, p. 518.

(38) Bk. Wieland, a.g.e., m. 676 (653), no. 6.

(39) Bk. Romer, a. g. e., sh. 70; Wieland, a. g. e., m. 676, no. 6; Bruggmann, a. g. e., sh. 55 - 56; İmre a. g. e., sh. 126 - 127.

(40) Aargau Yüksek Mahkemesi, SJZ, 32 (1935), sh. 378; Bern Kanton Mahkemesi, ZbJV, 68 (1932), sh. 545.

(41) Bk. aşağıda not. 110. 
bilirler. Üstlerinin kapalı olup olmaması haizi ehemmiyet değildir. Böylece üstü açık arklar, hendekler bir ırmağın kollarından biri mahiyetini taşımadıkça mecra sayllabilirler.

Sulama veya kurutma için yapılan büyük bentlere, eklüzlere mecra vasfimı izafe etmek yukarıda da söylediğimiz g:bi doğru olmaz (42). Ancak bu tesisatın birden fazla gayrimenkul üzerinde inşası gerektiği takdirde haklarında MK. m. 653 hükmü kıyasen tatbik edilebilir, fakat MK. m. 668 in bunlara teşmili caiz değildir.

Komşu gayrimenkulde bir havuz veya su haznesi tesisi için de MK. m. 668 e başvurulamaz (43); çünkü bu gibi tesisat suyun nakline değil birikme ve muhafazasına yarar.

Sun'î kaynaklarda suyun toplanması için yerleştirilmiş bir boru da birden fazla gavrimenkul dahilinde uzansa dahi bir mecradan ziyade bir kaynak noktası (Quellenpunkt) saylmalıdır (44).

bb) Gaz mecraları : Bu guruba yalnız toprağa yerleștirilmiş borular değil, ayni zamanda çukurlar, tanzim istasyonları, iki istasyon arasudaki hazneler gibi gazın tevziine yarayan tesisat da dahildir (45).

cc) Elektrik mecralarn (46) : Bunlar da elektrik enerjisinin nakil ve tevziine yarayan kablo, tel, direk, pilon, direk istinatgâhları, koruyucu tesisat, transformatörler, tevzi kutuları, mücerritler, bir duvar veya damdaki istinat noktaları gibi şeylerdir.

Bizzat elektriğgi istihsal eden makine ve fabrikalar mecralar hakkndaki hükiimlerden istifade edemæzler. Bunların başkasını gayrimenkulü üzerinde inşası için bir ïst halkı tes:sine lüzum vardır.

b) Medenì kanun açıkta olan mecralarla açıkta olmayanları da tefrik etmektedir (47). Bu tefrik mecra irtifak hakkının doğumu için tescile hacet olup olmaması bakımindan ehemmiyetlidir.

(42) Ayni fikirde Romer, a. g. e., sh. 69; Bruggmann. a.g.e., sh. 55; aksi fikirde Leemann, Komm, Art. 691; Nr. 4; Haab, Komm., Art. 676, Nr. 1.

(43) Ayni fikirde : Bruggmann, a. g. e., sh. 56, not 1; Haab, Komm., Art. 691 - 693, Nr. 9; aksi fikirde : Wieland, a. g. e., m. 691 (m. 668), no. 1.

(44) Federal Mahkeme karan RO 65 II 57 yahut Jd T, 1939, p. 487, «Güntert c. Kraftwerk Ryburg - Schwörstadt»; Romer, a. g. e., sh. 70; Imre, a. g. e., sh. 33

(45) Romer, a. g. e., sh. 71.

(46) Romer, a. g. e., sh. 71; Wieland, a. g. e., m. 676 (653), no. 6, m. 691 (668), no. 2.

(47) Medenî Kanun'un Fransızca ve Almanca metinlerinde kuilamlan görünürde olan» (apparent, ausserlich wahrnehmbar) tabiri belki saçıktas tabirinden daha iyi maksadi ifade etmektedir. 
Görünürde olan ve olmayan mecralar tefr:kini yer altı ve yer üstü mecralar tefrikiyle karıştırmamak lâzımdır (48). Filhakika bir mecra yer altında olmakla beraber muayyen aralıklarla bir takım kuyuların bulunması onun mevcudiyeti hakkında üçüncï şahıslara kâfi derecede fikir verebilir. Bu takdirde mecranın görünür olduğunu kabul etmek ve ona müteallik irtifak hakkını tescilden muaf tutmak gerekir (49).

\section{MECRA TESISINE MUTEALLIK IRTIFAK HAKKI}

\section{Mahiyeti.}

Mecra tesisine müteallik irtifak hakkı başkasının gayrimenkulünden bir mecra geçirmek ve onu muhafaza etmek salâhiyetini bahşeden bir nevi inşaat (üst) hakkıdır. Bu irtifak hakkı bir gayrimenkul irtifak hakkı yahut da şahsî bir irtifak hakkı olarak tesis edilebilir (50). Birinci halde hak sahibi, mecrayı koymuș olan teșebbüsün üzerinde bulunduğu gayrimenkulün her maliki (51) ikinci halde ise teşebbüsü işleten muayyen bir şahıstur.

Şu noktayı ehemmiyetle kaydetmek lâzımdır ki, MK. m. 653 de beyan edilen, mecranın eseri olduğu teşebbüsün teferruatı sayılması ve görünürde olan mecralara ait irtifak hakkının tescilden muaf tutulması esasları ancak bir gayrimenkul irtifak hakkı mevcut olduğu takdirde tatbik edilebilirler. Bu husùs İsviçre hukukçuları tarafından müttefikan kabul olunmuş bulunmaktadır (52).

Türk hukukunda Prof. Hirș aksi kanaati müdafaa etmektedir (53). Sayın Hocamıza göre, MK. m. 653 ün tatbiki için gayrimenkule müteallik bir irtifak hakkının mevcudiyeti şart kılınırsa, sınầ teşebbüslerin makinelerini kiraladıklan arsa üzerinde kurmaları veya gayrimenkul malikinin işletmesini hasılat icrasina vermesi hallerinde mezkûr madde hükmünden istifáde mümkün olmayacaktır. Bundan başka, sınaî teșebbüs imalâthanesini bulunduğu gayrimenkulden diğer bir gayrimenkule

(48) Haab, Komm., Art. 676, Nr. 10, bu karıştırmayı yapmaktadır.

(49) Ayni kanaatte : Romer, a. g. e., sh. 71

(50) Haab, Komm., Art. 676, Nr. 8

(51) Veya teşebbüs başkasının arsası üzerinde devaml $l_{1}$ ve müstakil bir üst hakkına binaen kurulmuş ve bu hak gayrimenkul olarak tapu sicilinin ayrı bir sahifesine kaydedilmiş ise bu ahak - gayrimenkulün» her maliki.

(52) Haab, Komm. Art. 676, Nr. 10 ve 15; Leemann, Komm., Art. 676, Nr. 15 ve 22; Wieland, a. g. e., m. 676 (653), no. 5; Romer, a. g. 'e., sh. 74; Bruggmann, a. g. e, No. $86-87$

(53) Hirs, a. g. e., sh. 55 - 57 
naklettiği takdirde, eski gayrimenkul lehine doğmuş olan irtifak hakları sukut edecek vel diğgr gayrimenkul lehine doğacaktır. Bütün bu neticeleri önlemek için, Prof. Hirş’in fikrince, aç̧kta bulunan mecraların döşenmesiyle, teşebbüsü işleten şalus lehine şahsî bir irtifak hakk doğduğunu ve böyle bir hakka binaeı konan mecralarn MK. m. 653 deki teferruat prensibinden istifade ećebileıeklerini kabul etmek lâzımdır.

Sayın Profesör fikrini isbat bâbinda şu mülâhazaları serdetmektedir: MK. m. 653 hükmünde bir gayrimenkul irtifak hakkının mevcudiyetinin şart kılındığ lemez. \&.. Bu maddedeki hüküm yabanc1 gayrimenkuller üzerinde irtifak hakkının tesis suretine mütealliktir. Lehine irtifak hakkı tesis edilen gayrimenkulden bahsedilmemiştir. Bilâk:s metinlerden irtifak hakk1nın sınaî müessesenin sahibi yani müteșebbisin lehine doğduğu nøticesi çıkmaktadı.... MK. m. 652 de sınai teşebbüsün sahibinden bahsedilmiştir. Mâlik tabiri yerine sahip lielimesinin kullanılmış olması câlibi dikkattir. Bu ibareden maksat, smầ teşebbüsün maliki değil, TK. m. 125 bent 7 ve $\mathrm{m}$. 126 mucibince müteşebbistir. Bir teșebbüsü kiralayan veya işleten şahıs, gayrimenkulün, makinelerin, diğer tesisatın ve işletme vasitalarmnn maiki olmasa da, müteșebb:s addolurur. Binaenaleyh 653 üncü maddedeki irtffak talirini mantıki bir tarzda tefsir etmekliğimiz icab ederse, bu ibare ile gayrmenlkule müteallik bir irtifak hakkınn değil, Medenî Kanun'un 753 üncii maddesinin kabul ettiği mânada mahdut ve şahsì bir irtifak hakkı kastedilmiş olduğunu anlarız. Sinaî teşebbüsün sahibi lehine teessüs edeni irtifak hakkının vüsat ve şümulü, hak sahibinin ihtiyacnna bağlıdır. Mecra hakkı, inşaat hakkımm hususî bir şeklinden başka bir şey olmadığmdan, Medenî Kanun'un inşaat hakkına mütclallik 751 inci maddesi 'oure.da da tatbik edilebilir. Meselâ, hak sahibi, satșs neticesi olarak veya nüessesenin kiraya verilmesi veya diğger bir müessese ile birleşmesi suretiyle değişecek olursa, esas şartlar değişme diğinden irtifak hakkı da sukut etmeyecektir. Diğer taraftan teşebbüs, fabrika mahallini değiștirecek yani imalâthanesini başka bir yere nakledcek olursa, irtifak hakkı gayrinenkule değil, bilâkis teșebbüse bağlı olduğundan, irtifak hakk bu halde de düşmeyecektir (54),

Prof. Hirş’’n ileri sürdüğü tez ilk bakışta cazip görünmesine rağmen muhtelif bakımlardan tenkicl edilebilir :

a) İsviçre Medenî Kanunu’nun bizim kanunumuzun 653 üncü maddesine tekabül eden $676 \mathrm{nc1}$ maldesi, fransizca ve almanca metinlerinde,

(54) Hirş, a. g.e., sh. 56 - 57. 
sarahaten «teşebbüsün maliki» (propriétaire de l'entreprise, Werkeigentümer) ibaresini ihtiva etmektedir. Türkçe metinde de sahip tabiri, herhalde, «malikin mülkü» gibi kulağa hoş gelmeyen bir ifade tarzından kaçınmak için kullanılmıştır. Yoksa zaten malik mânasına gelen sahip tâbirinin mevcudiyetinden bir takım neticeler çıkartmak ince bir kelime oyunundan başka bir şey değildir.

b) İsviçre'de Metdenî Kanun'un hazırlanması " esnasında Conseil d'Etats'da cereyan eden müzakereler 653 üncü maddedeki tescil muafiyetinin sadece gayrimenkule müteallik bir mecra irtifak hakkı için bahis mevzuu olabileçeğini açıkça göstermektedir (55).

c) Görünürde olan mecraların bizzat mevcudiyeti bunların hangi gayrimenkule hizmet ettikleri hakkında üçüncü şahıslara kâfi derecede fikir vermektedir ve lehinel mecra irtifak hakkı doğan gayrimenkulün malikini tapu sicilinden her vakit öğrenmek mümkündür. Halbuki tapu sicili müteşebbisin kim olduğu hakkında malûmat vermez. Bu itibarla müteșebbis lehine kabul edilen ve tescilden muaf tutulan şahsî bir irtifak hakkı kâfi derecede aleniyet ve muayyeniyetten mahrumdur.

d) Mecraların bizzat kendileri müstakil bir gayrimenkul teşkil etmediklerinden rehin veya ferağ edilebilmelêri ancak hâk:m bir gayrimenkule teferruat olarak bağh bulunmaları ve bu gayrimenkulün rehin veya ferağ edilmesiyle mümkündür. Şahsî irtifak hakkında hâkim bir gayrimenkul bahis mevzuu olamıvacağına göre böyle bir hakka müsteniden tescilsiz tesis eldilen açıktaki mecraların da rehni veya ferağı kabil olamaz. Meğer ki bu șahsî irtifak hakkı, müstakil ve devamlı bir hak vasfını haiz olarak, bir gayrimenkul gibi tapu sicilinin ayrı bir sahifesine kaydedilmiş olsun. Bu takdirde de tescil muafiyetinin bir manası kalmamış olacaktır.

Demek ki teşebbüs makinelerini kiraladığı bir arsada kurmuşsa döşediği mecralar üzerinde tasarruf edebilmesi ancak bunlara müteallik şahsî mahiyetteki irtifak haklarının gayrimenkul olarak kaydedilmelerine tabidir. Bu sebeple geniş ölçüde devamlı şebekeler tesis edecek bir teşebbüsün makinelerini ya kendi arsası üzerinde kurması veya bu makineler için başkasımın arsası üzerinde, tapu siciline gayrimenkul olarak kaydedilen, devamlı ve müstakil bir inşaat hakkı temin etmesi tavsiyeye şayandır; teşebbüs ancak böylece kendisine mecralar üstündel kolayca tasarruf imkânını bahşeden bir gayrimenkul irtifak hakkına sahip olabilir.

(55) Bull. Sten., C. E., 1906, pp. 533 et 1266; Wieland, a. g. e., m. 676 (653), no. 5 . 
e) Bir sınaî teşebbüsü hasılat icarına alan kimsenin vaziyetine gelince, bu şahsın, teşebbüsün daha öncəden kurmuş olduğu ve onun mülkiyetine dahil olan, mecralar üzerinde temlik veya terhin gibi tasarruflarda bulunması mümkün değildir. Binaenaleyh mecra hakkının mahiyettinin gayrimenkul irtifak hakkı olarak kabul edilmesinden teșebbüsün hasllat icarına verilmesi halinde ne mahzur husule geleceğini tasavvur etmek müşküldür. Eğer müstecir yeni mecralar kurmuşsa bunlar da teşebbüsün mülkü olur ve icar münasebetin:n hitamında müstecir bunlar için münasip bir tazminat talep edebilir (BK. m. 293, f. III) veya mümkünseł onları sökebilir.

f) Prof. Hirş, mecra tesisine müteallik şahsî irtifak hakkında hem MK. m. 753 ün kabul ettiği mânada mahdut bir irtifak hakkı hem de MK. m. 751 de bahsi geçen bir inşaat hakkı mahiyetini görmektedir. Halbuki bu haklardan ilki hilâfına mukavele bulunmadıkça başkasına temlik olunamıacağ si için aksi kaide câridir.

g) Nihayet, teşebbüsün imalâthanesini başka bir gayrimenkule nakletmesi halinde eski gay:imenkul lehine olan irtifak hakkmin sukut edip yeni gayrimenkul lehine bir irt fak hakkı doğmasında, bu yeni irtifak hakkı da (55a) tescile tabi olmavacağına göre, ne gibi bir mahzur mülâhaza edildiği de anlaşlamamaktadır.

Hülâsa, MK. m. 653 f. I vel III deki teferruat ve tescil muafiyeti esaslarının şahsî bir irtifak hakkının mevcudiyeti halinde tatbiki bahis mevzuu olamaz.

2. Mecra tesisine müteallik irtifak hakkının doğması ve sona ermesi.

a) Doğumu: MK. m. 704 f. II mucibince khilâfına sarahat bulunmadıkça, mülkiyet hakkındaki hükümler irtifak hakkının iktisap ve tescilinde dahi caridir» (56). Gayrimenkul mülkiyetini iktisabın muhtelif tarikleri MK. m. 653 ve müteakipte sayılmaktadır. Bu iktisap yollarından mukavele, mecra irtifak hakkının tesisi bakımından en bașta gelenidir. Di- ğer taraftan iktisabî müruruzaman, mahkeime kararı ve istimlâk vasıtasiyle de bir mecra irtifak hakkının doğabileceği söylenmektedir.

aa) Bir mukavele ile mecra irtifak hakkını tesis edebilmək için bu mukavelenin resmî şekilde yapılmış olması lâzımdır (MK. m. 705) (57). Bundan başka, eğer mecra görünürde değilse, ona müteallik irtifak hakkının

(55 a) Mecra açıta ise.

(56) MK. m. 753 f. III e binaen, gayrimenkule müteallik irtifak hakkına dair hükümler kıyasen şahsı irtifak haklarının tes.sinde de tatbik olunabilir.

(57) IMK. m. 732 ye göre bu hususta yazılı şekil kâfidir. 
doğabilmesi bu hakkın tapu siciline tescil edilmesine bağlıdır (MK. m. 653 f. I.cümle 1). Telscil, gayrimenkulünden mecra geçirilecek mâlikin tahriri talebi ve tapu memuru tarafından tanzim edilen resmî mukavelenin ibrazı üzerine yapılır (MK. m. 922 f. I ve Tapu Sicilli Nizamnamesi, m. 14,19 ve 20 ).

Açıta olan mecralara müteallik irtifak hakkı, daha yukarıda da muhtelif vesilelerle işaret edildiği gibi, mecranın yapılmasiyle teessüs etmiş olur (MK. m. 653 f. III cümle 2) Haricen görünür bir şekilde bir başka gayrimenkule hizmet eden mecranın mevcudiyeti, kanun vazınca irtifak hakkının aleniyetini temin için kâfi addedilmiş ve bu hak tescilden muaf tutulmuştur. Böylece tescilsiz olarak doğan mecra hakkı, mahiyeti itibariyle ancak gayrimenkule müteallik bir irtifak hakkı olabilir (58).

Isviçre hukukunda, tescil muafiyetinden, irtifak hakkının tesisi için şekle bağlı bir mukavele yapmak mecburiyetinin de ortadan kaldırıldığı neticesinin çıkarlamayacağı umumiyetle kabul edilmektedir (59). Başka bir deyimle, Isviçre hukukçularına göre, mecra açıkta kurulacak olsa dahi evvelâ üzerinden geçirileceği gayrimenkulün malikiyle yazılı bir anlaşma akdetmek lâzımdır. Kanaatımızca, bu görüş tarzının Türk hukukunda da müdafaası menfaatler vaziyetine uygun düşmez. Filhakika, biraz evvel de kaydettiğimiz veçhile, tsviçre Medenî Kanunu'nun 732 nci maddesi irtifak hakkını tesis eden mukavelenin yazılı şekilde yapılmasını kâfi gördüğü halde Medeni Kanun'umuzun 705 inci maddesi bu hususta resmî şekli aramaktadır. Bundan başka, memlekeţimizde, Tapu Kanunu’nun 26 ncr maddesi mucibince mülkiyete ve mülkiyetin gayri aynî haklara müteallik resmî senetleri tanzime noterler salâhiyetli olmayıp, bu senetler ancak tapu sicil muhafizları veya memurlan tarafindan yapılabilir. Bu itibarla görünürde olan mecralara müteallik bir irtifak hakkınm teessüsü için resmî bir mukavele yapılması istenecek olursa tescil muafiyetiyle önlemek istenen zahmet ve masrafların büyük bir kısmı gene baki kalacaktır. Binaenaleyh Türk hukukunda tescil muafiyetinin resmì mukavele yapmak mecuriyetini de ortadan kaldırmış olduğunu kabul etmek memleketimizin icapları bakımından daha isabetli olur. Zaten MK. m. 653 f. III metni de sarahaten «mecra açıta ise irtifak hakkı mecranın yapılmasıyla teessüs etmiş olur» demekte ve resmî bir muka-

(58) Bk. yukarida IV, I.

(59) Haab, Komm., Art. 676, Nr. 9; Romer, a. g. e., sh. 74; Leemann, Komm. Art. 676, Nr. 11; Pern Kantonu Adalet Direktörlüğü, SIZ, 13 (1916) W. Meier. Das Telephonregal nach schweizerischem Recht, Diss. Bern, sh. 113, yazıli mukaveleye sadece bir isbat vasitası mahiyetini izafe etmektedir. 
veleden bahsetmemektedir.

Görünürde olan mecralara müteallik irtifak hakkın tescilden muaf tutan hüküm âmir mahiyette değildir. Mecra kuran dilerse, MK. m. 668 f. II ye kiyasen, masrafı kendisine ait olmak üzere mecra hakkını tescll ettirebilir (60). Daha basit ve ucuz olan diğer bir yol da tapu sicillinde, hâdim gayrimenkulün evsafını tayin eden sütuna mecra hakkının şerh verilmesi olup buna kanunî bir mani de yoktur (61). Bu şekilde ihtiyatlı hareket etmek bazan faydalı olabilir. Filhakika hâdim gayrimenkulün maliki açıtaki mecrayı kaldırıp gayrimenkulü hüsnüniyetli bir üçünciu şahsa devrederse bu şahıs, ortada mecra ve tapu sicilinde de tescil veya şerh bulunmadığından, şeyin mülkiyetini irtifak hakkından âri olarak iktisap eder (62). Halbuki tescil veya şerh, mecra kaldırılmıs olsa dahi. irtifak hakkının sonraki maliklere karşı da dermeyanını mümkün kılar.

Açıkta olan mecralara müteallik irtifak hakkının tescilsiz doğması bazan mecranın katettiği gayrimenkulün maliki aleyhine şöyle bir netice ortaya koyabilir: Malik mülkünde bir mecra tesisi hususunda smaì bir teşebbüse muvakkat bir müsaade vermiş olabilir; eğer bu mecra görünürde ise teşebbüsün bulunduğu gayrimenkulü hüsnüniyetle iktisap eden üçüncï şahıs lehine mecraya müteallik bir irtifak hakkı doğar (63). Böylece muvakkat müsaade bir irtifak hakkina inkılâp etmiş olur.

b) Mecra irtifak hakkının mukaveleden başka bir sebebe binaen iktisabına tatbikatta daha nadir rastlanır.

MK. m. $704 \mathrm{f}$. III e tevfikan, bir mecra irtifak hakkına, müruruzaman neticesinde sahip olmak mümkündür (64).

Hâdim gayrimenkulün mülkiyetinin mürurưzamanla iktisabı için gerekli şartlar hakkındaki hükümler kıyasen burada da tatbik edilir. Binaenaleyh mecra hakkmın alelâde müruruzamanla kazanılması için: evvelâ, mecra kuran, mecranın geçirilmesine riza gösteren şahsın mülkiyet hakkınn mevcudiyetini ve tesisin dayandığı sebebin muteberiyetini ka-

(60) Haab, Komm. Art. 676, Nr. 10; Wieland. a. g. e., m. 676 (653), No. 9e. Tapu memuru tescilden muaf irtifak hakkın Kantonu Adalet Direktörlüğü, SJZ, 13 (1916), sh. 71, No. 50

(61) Haab, Komm. Art. 676, Nr. 10

(62) Wieland, a. g. e., m. 676 (653), No. 10, b.

(63) Wieland. a.g. e., m. 676 (653), No. 10, b.

(64) Şahsî mahiyetteki bir mecra irtifak hakkının müruruzaman ile iktisap edilip edilemeyeceği çok münakaşalıdır. Bu hususta bk: Pierre Tuor : Code civil suisse, Exposé systématique, trad. par Deschenaux, Zürich 1942, sh. 537 ve o sahifede not 34 te zikredilen müellifler. 
bul hususunda hüsnüniyetli olmalı; saniyen, fasılasız ve nizasız olarak mecra hakkını on sene müddetle istimal etmiş bulunmalıdır (65). Ĕger hadim arazi MK. m. 639 daki şartları arzediyorsa, nizasız ve fasılasız olarak yirmi sene müddedle ve irtifak hakkı sahibi sıfatıyla, o araziden geçen mecradan istifade eden hâkim gayrimenkulün maliki fevkalâde müruruzamanı ileri sürebilir (66).

Temyiz Mahkemesi 1. Hukuk Dairesi yeni bir kararında (66a), kâfi derecede sarahaten olmamakla beraber, bir mecra irtifak hakkının müruruzamanla iktisap edilebileceğini kabul eder görünmektedir. Karar şu mealdedir: «Evvelki malikin davacınm su harkını geçirmesine senelerce (hadisede 10 - 15 sene) müsamaha ettiği şahadetle sabit olduğuna ve tarlasından komşunun su harkını geçirmesine müsamaha ve müsaade etmiş olan kimsenin sonradan bundan geri dönemeyeceğine ve bu gibi açıta olan harklarmn tesciline de kanunî bir mecburiyet bulunmadiğına ve bu gibi hakların üçüncü şahıslara karşı ileri sürülebileceğine göre......» Yüksek Mahkeme su harkını geçirmek hususunda verilen müsaadeden dönülemєyeceğini beyan ettiğine göre bu müsaadede bir muvakkat işgale müsamahadan ziyade bir irtifak hakkınm tesisine rıza gösterme mahiyetini görmektedir.

Diğer taraftan Mahkemenin su harkının açılmasını komşuluk münasebetlerine müstenidmiş gibi telâkki ettiği hususunda hiçbir emare yoktur; filhakika böyle olsaydı hadisede MK. m. 668 in şartlarını tahakkuk edip etmediğini araştırması gerekirdi. Hulâsa 1. Hukuk Dairesinin bu kararnndan, onun, açıkta olan su harkına müteallik irtifak hakkının, harkın yapılmasıyla (66 b) veya iktisabî müruruzamanla doğduğunu kabul ettiği neticesine varabiliriz.

Daha yukarnda da temas ettiğimiz veçhile (67). Isviçre'de mecra irtifak hakkının istimlâk yoluyla tesis edilebileceği umumiyetle kabul olunmaktadır. Memleketimizde halen mer’i istimlâk mevzuat bakımından bu yola gidilmesi mümkün görünmemektedir. Bununla beraber ayni esasın bizde de kabulü temenniye şayandır. Istimlâk yoluyla tesis edilen mecra hakkı tescilsiz doğar. Ancak üçüncü şahısların hüsnüniyet iddialarm bertaraf etmek maksadiyla koruyucu mahiyette bir tescil yapturılabilir. Açıkta olan mecralar için bu koruyucu tescile dahi ihtiyaç yok-

(65) (66) Wieland, a. g. e., m. 731 (704), No. 5

(66 a) 19. 2. 1951 , E. 6468/K. 1425 (Tepeci, a. g. e., Cilt III, Ankara 1952, sh. 265).

(66 b). Bk. yukarida aa).

(67) Bk. yukarıda not 25 . 
tur; mecra mevcut olduğu müddetçe üçüncü şahıslar hüsnüniyet iddiasında bulunamazlar (68).

Haab (69) ve Leemann (70) mahkeme kararyla da bir mecra irtifak hakkının doğabileceğini söylemektedirler. Mecra hakkının bu suretle tesisinin pratik bir misalini bulmak oldukça müşüuldür. Belki iştirâk halinde veya müşterek mülkiyete mevzu teşkil eden bir gayrimenkulün taksiminde, mahkeme taksim neticesinde ortaya çıan parçalardan birinden geçen mecra üzerinde diğer parça lehine bir irtifak hakkı tanıyabilir (70). Bundan başka mecra hakkına müteallik yanlış bir tescilin tashihi davasmda da hâkim hükmüyle mecra hakkınn tanıması mümkündür (71).

Bir kimse maliki olduğu iki gayrimenkulden biri lehine diğeri üzerinde bir mecra hakkı tesis edebilir (MK. d. 706) (72). Böyle bir hakkın tesisi için malikin tapu memuruna bir talepname vermesi kâfidir (Tapu Sicilli Nizamnamesi, m. 21). Bu suretle yapilan tescilin faydası, gayrimenkullerden birinin veya her ikisinin malikin elinden çıkması halinde kendini gösterir.

Mecra irtifak hakkının tesisi hakkındaki izahatımızı tamamlamadan önce şu noktaya da işaret etmek lâzımdır: Medenî Kanun'un meriyete girmesinden evvel müesses gayrimenkule müteallik mecra irtifak hakları gayrimenkul sicillerinin teşkilinden sonra tescil ettirilmemiş olsalar dahi bâki kalırlar; yalnız mezkûr hakların hüsnüniyet sahibi üçüncü şahıslara karşı dermeyan edilebilmeleri tescilleri tarihinden itibaren mümkündür (Kanunu Medenînin sureti meriyet ve şekli tatbiki hakkında Kanun, m. 22). Bu husus Temyiz Mahkememizin içtihatlarıyla da teyid edilmiş bulunmaktadır (73).

b) Mecra irtifak hakkı tapu sicillindeki tescilin terkini veya alâkadar iki gayrimenkulden birinin büsbütün zayi olmasıly sâkıt olur (MK. 707).

Hâdim gayrimenkul mâliki tescilin terkinini muhtelif sebeplere binaen istiyebilir (74):

aa) Terkini isteme hakkı bir hukukî muameleye istinat edebilir. Ezcümle mecra sahibi, irtifak hakkından tek taraflı olarak veya hâdim

(68) Haab, Komm. Art. 676, Nr. 11.

(69) Haab, Komm, Art. 676, Nr. 8; Leemann, Komm. Art. 676, No. 12.

(70) (71) Wieland, a.g. e., m. 731 (704), No. 3 b.

(72) Wieland. a.g.e., m. 676 (653), No. 11.

(73) 4. H. D., 15. 10. 1943, E. 2838/K. 2779; H. U. H. 25. 12,1940 (Bk, Kâmil Tepeci : Notlu ve İahlı Türk Kanunu Medenisi, cilt 2, Ankara 1946, sh. $106-108$ ).

(74) Wieland, a.g. e., m. 734 (707), No. 1 ve 3. 
gayrimenkul mâlikinden aldığ 1 bir ivaz mukabilinde feragat etmiş olabilir. Bu suretle doğan terkini isteme hakkı hâkim gayrimenkulü sonradan iktisap eden üçüncü şahıslara dermeyan edilemez.

bb) Terkin, bir kanun hükmüne müsteniden de istenebilir; bu takdirde hâkim gayrimenkulü sonradan iktisap edenler dahi terkine rıza göstermekle mükelleftirler. Bu hususta şu misaller sayılabilir: Eğer mecrayı idamede hâkim gayrimenkul malikinin hiç menfaatı kalmamışsa veya mecra mucip olduğu külfete göre pek az menfaat temin ediyorsa (75) hâdim gayrimenkulün sahibi mecra hakkının terkinini talep edebilir (MK. m. 709). Hâkim veya hâdim gayrimenkulün taksimi hallerinde de mecradan istifade etmeyen veya üzerinden mecra geçmeyen kısımlara râci olmak üzere irtifak hakkının terkini talebinde bulunulabilir (MK. m. 715 ve 716$)$.

cc) Bazı hallerde mecra hakkı terkinden önce sukut eder. Irtifak hakkı muayyen bir müddet için tesis edilip de bu müddet hitam bulmuşsa, hâkim hükmü veya istimlâk yoluyla hakka son verilmişse vaziyet böyledir. Bu gibi hallerde henüz terkin edilmemiş olan tescil sadece şeklî bir mevcudiyeti haizdir. Bununla beraber hâkim gayrimenkul temlik edilirse, bu tescile binaen, hüsnüniyetli olan yeni malik lehine, maddî bakımdan sukut etmiş olan irtifak hakkı yeniden doğar. Bu neticeyi önlemek için, sadece şeklen mevcut tescili bir an evvel terkin ettirmek ve icabında terkine kadar bu hususta muvakkat bir șerh verdirmek (MK. m. 921) lâzımdır.

Açıta olan mecralara müteallik irtifak hakk1, mecra bizzat hak sahibi tarafından veya onun rızası alınarak kaldırılırsa, sukut eder (76). Eğer böyle bir irtifak hakkı ihtiyaten tapu sicilline tescil edilmiş veya şerh verilmişse; hak mecranın kaldırılmasına rağmen mevcudiyetini muhafaza eder (77).

Mecranın takyid ettiği ve ondan istifade eden gayrimenkuller ayni kimsenin mülkünde birleşirlerse, o kimse irtifak hakkını terkin ettirebilir (MK. m. 708 f. I). Fakat malik ileride gayrimenkullerin elinden çıması ihtimalini düşünerek terkinden sarfınazar edebilir. Bu takdirde mecra hakkı mevcudiyetini muhafaza eder (MK. m. 708 f. II).

3. Mecra tesisine müteallik irtifak hakkınm hükümleri :

Umumiyetle gayrimenkul irtifak hakkının hükümlerine müteallik kaideler mecra hakkına da tatbik edilirler (78):

(75) Bu takdirde bir tazminat mukabilinde.

(76) Haab, Komm. Art. 676, Nr. 11; Wieland. a. g. e., m. 676 (653), No. 9. g

(77) Bruggmann, a. g. e. . sh. 89 
Mecra hakkının şümulü MK. $\mathrm{m}$. 710 ve müt. e göre tayin edilir. Mecra hakkı sahibi hakkını muhafaza ve ondan istifade için iktiza eden bütün tedbirleri ittihaz edebilir (MK. m. 710 f. I); her zaman hâdim gayrimenkule girebilir ve mecraların gerektirdiği tamiratı icra edebilir, yeter ki bunun için hâdim gayrimenkul maliki bakımından gayri müsait bir zaman intihap etmiş olmasın. Filhakika hak sahibi hakkını ancak tahmil edilen gayrimenkulün malikine en az zarar verecek bir tarzda kullanmakla mükelleftir (MK. m. 710 f. I). Gene bu sebepten mecra sahibi mecranın kurulması için gerekli işleri münasip bir zamanda ve mümkün olduğu kadar çabuk ifa etmeli, yapılan hafriyatı doldurmalıdır. Bundan başka mukayyet gayrimenkulün malikine, sebebiyet verdiği zararı tazmine ve mutabık kalınan ivazı ödemeğe mecburdur (79).

Mecra hakkmin muhteva ve şümulünü tayinde, eğer hak tescil edilmişse bu tescil ve, mecranm bidayetteki konulma ve uzun bir müddet nizasız olarak hüsnüniyetle kullanılma tarzı gözönünde tutulur (MK. m. 711).

Takyid edilen gayrimenkulün maliki, mecra kuranın yeni ihtiyaçları dolayısıyla, mecra şebekesinin ehemmiyetli surette tevsiine müsaade etmekle mükellef değildir; bununla beraer mecra sahibi mükellefiyetin hissolunur derecede tezayüdünü istilzam etmeyen tadjlâtı yapmakta hak. lıdır, meselâ işletme için bidayette lüzumlu olmayan bazı telleri sonradan ekleyebilir (80).

Mecranm bakım ve muhafazası MK. m. 713 mucibince irtifak hakkı sahibine terettüp eder; fakat, hâdim gayrimenkul mâliki, bir mukavele ile, bakım külfetini üzerine alabilir (MK. m. $703 \mathrm{f}$. II). Elektrik tellerinin katettiği arazi ormanlıksa arazi sahibine ağaçları budamak mükellefiyeti yüklenebilir (81).

Mecralarm bir yerden diğer bir yere nakli hususunda, komşuluk münasebetlerine müsteniden tesis edilen mecralar hakkındaki MK. m. 670 hükmü (82) kiyasen tatbik edilir (MK. m. 714 f. II).

Mecra hakkından istifade eden veya bu hakkın takyid ettiği gayrimen-

(78) Wieland, a. g. e., m. 676 (653), No. 11; Haab, Komm., Art. 676, Nr. 8 Bruggmann, a.g.e., sh. 77.

(79) Wieland, a.g.e., m. 676 (653), No. 11.

(80) Wieland. a. g. e., m. 676 (653), No. 11.

(81) Haab, Komm., Art. 676, Nr. 8

(82) $B k$, aşağıda $B$ kısmı, V, 3. 
kulün taksimi hallerinde MK. m. 715 ve 716 hükümlerine başvurulmalidur.

Tescil edilmiş mecra haklarının sırası yevmiye defterine kayıt zamanına göre tayin olunur (MK. m. 930 ve Tapu Sicilli Nizamnamesi, m. 15). Tescile tabi olmayan mecra hakları mecranın haricen görünebilecek tarzda yerleştirilmesi anından itibaren doğarlar ve sıra alırlar (83).

\section{MECRALARIN MULKIYETI}

I. Mecraların mülkiyetinin kime ait olacağı meselesinin ehemmiyeti. «Superficies solo cedit» prensibi.

Mecraların mülkiyetinin kime ait olacağ lardan ehemmiyet arzeder.

Mecralar muayyen bir mamelekî kıymeti haizdirler ve tesisleri geniş ölçüde masraf yapılmasını icap ettirir. Bu itibarla, mülkiyetlerinin kime ait olacağı ve üzerlerinde kimin tasarruf edebileceği sualinin cevabı, bilhassa bunları tesis eden kimse veya teşebbüs bakımından, mühimdir.

Diğer taraftan, bir sinaî teşebbüsün bir gayrimenkul dahilinde kurduğu mecra üzerinde, ondan başka gayrimenkullere kollar ayırmak suretile tasarrufu ancak teșebbüsün bu mecranun mülkiyetine sahip olmasi halinde mümkündür (84).

Bundan başka, mecralar su, gaz, elektrik gibi dağlması ve yayılmasi tehlikeli bir takım kuvvet ve maddelerin nakline hizmet ederler. Bu kuvvet ve maddelerin mecra dişma çlkmasından doğacak zararlar mec- $\nsucc$ ra malikinin mes'uliyetini intaç ederler. Filhakika mecralar gayrimenkul şeylerden sayıldıklarından (85) bunların maliki MK. m. 656 ya tevfikan mes'ul tutulabilir. Ayni zamanda mecralar «imal olunan şey» mefhumuna da girdiklerinden maliklerinin, BK. m. 58 e binaen de, mes'uliyeti yoluna gidilmesi mümkündür (86).

Nihayet, gayrimenkul maliklerine yükletilen amme hukuku mükellefiyetleri ve vergiler mecra sahibi için de bahis mevzuu olur (87).

MK. m. $644 \mathrm{f}$. II de ifadesini bulan «superficies solo cedit» prensibi mucibince gayrimenkul mülkiyeti arazi dahilinde yapılan şeyleri (inşaatı,

(83) Haab, Komm., Art. 676, Nr. 8; Wieland, a.g.e., m. 676 (653), No. 9 , b; Leemann, Komm. Art. 676, No. 13.

(84) Bk. Ankara Asliye Mahkemesi 2. Ticaret Dairesinin 2.12.1948 tarihli neştolunmamış kararı (E. 312/K. 133).

(85) Bk. aşă̆ıda VI, 2 c.

(86) Haab, Komm. Art. 676, Nr. 7; Leemann, Komm, Art. 676, No. 30.

(87) Federal Mahkeme'nin "Bernische Kraftwerke c. Commune de Wimmis davasında verdiği karar : RO 48 I 449 yahut Jd T, 1923, p. 327. 
constructions, Bauten) şamil olur. Arazinin altından veya üstünden geçmek üzere sıkı ve devamlı surette yerleştirilen mecralar da bir nevi inşaat teşkil ettiklerinden esas itibariyle bu prensibin hükmüne tabi tutulmaları gerekir (88). Fakat meckaların mülkiyeti hakkında, bu prensibe n kadar çok istisna kabul edilmiştir ki prensip mecralar bakımından ehemmiyetini hemen tamamen kaybetmiş bulunmaktadır.

2. Mecraların mïlkiyetinin kendisinden inbias ettikleri teşebbüsün sahibine ait olduğu haller.

a) MK. m. $653 \mathrm{f}$. I gereğince, mecralara, hangi sınaî teşebüsün eseri iseler onun sahibinin mülkü nazariyle bakllır.

Bu hükmün tatbiki için mecranın ayni maddenin ikinci fikrasında derpiş edilen şekilde tesis edilmiş olması lâzımdır. Yani mecra bir irtifak hakkına veya komşuluk münasebetlerine (MK. m. 668) binaen kurulmuş olmalıdır. Irtifak hakkı gayrimenkule müteallik veya şahsî mahiyette olabilir. Irtifak hakkınm sona ermesi halinde tekrar «superficies solo cedit» prensibi carî olur ve mecra, üzerinden geçtiği gayrimenkulün malikinin mülkiyetine avdet eder (89). Yalnız bu takdirde, irtifak hakkı sona eren şahsa mecrayı kaldırıp götürmek salâhiyeti tanınmalıdır (90).

Müelliflerin umumiyetle kabul ettikleri veçhile (91), komşuluk hakkına müsteniden kurulan mecraların mülkiyetinin bunları kuran teşebbüse ait olacağı prensibi, evleviyetle mecraların âmme menfaati için vazedilmiş bir mülkiyet takyidine binaen tesis edildikleri hallerde de tatbik edilmelidir.

b) Isviçre'de, amme emlâkine dahil gayrimenkuller üzerinde bir idarî tasarrufa dayanarak yerleştirilen mecraların mülkiyetinin, eseri oldukları teşebbüse ait olacağı hususunda doktrinde (92) ve mahkem içtihatlarma (93) tam bir ittifak mevcuttur. Wieland'a göre (94) bu gibi mecraların üzerinden geçtikleri amme emlâkinin birer mütemmim cüz’ü sayılmaması şu mülâhazalarla kabili izahtır :

(88) Bruggmann, a. g.e., sh. 80; Haab, Komm, Art. 676, Nr. 7

(89) Federal Mahkemenin yukarıda not 87 de zikredilen kararı : Jd T, 1923, p. 326.

(90) Wieland, a. g. e., m. 676 (653), No. 10, a

(91) Wieland, a. g. e., m. 676 (653), No. 3, b; Haab, Komm., Art. 676, Nr. 7; Leemann, Komm. Art. 676. No. 19.

(92) Haab, Komm., Art. 676, Nr. 7, Art 667, Nr. 18; Wieland. a. g. e., m. 676 (653), No. 3, c; Leemann, Komm., Art. 675, Nr. 25; Romer, a. g. e., sh. 75.

(93) Federal Mahkeme: 64 I 225 yahut Jd T, 1939, p. 180, «Güntert c. Kraftwerk Ryburg - Schwörstadt"; 56 III 65, "Bergaufzug Patent Feldmann A G."

(94) A. g. e., m. 675 (652), No. 4, c. 
Evvelâ, ticaret dişında bırakılmış olan amme emlâkine dahil gayrimenkuller bakımından tapu sicilline olạn umumî itimad prensibi bir fayda arzetmez ve binaenaleyh mecralarn mütemmim cüz'ü sayllmamasindan üçüncü şahıslar için bir mahzur doğmaz.

Saniyen, amme emlâki malikinin yapılan tesisatın kıymetine sahip olmakta bir menfaati yoktur. Onun için ehemmiyetli olan, emlâkin tahsis cihetinin mecraların konmasıyla değişmemesidir.

Türk idare hukukunda hâkim olan telâkkiye göre (95), eğer mecralar bir amme hizmeti yapmak için kendisine imtiyaz verilmiş olan bir teşebbüs tarafından tesis edilmişlerse, teşebbüs bu mecraların maliki olmadığı gibi onlar üzerinde bir aynî hak sahibi de değildir. Fikrimizce, eğer amme emlâkini kateden mecralar bir amme hizmeti için kurulmamışlarsa bunlarm mülkiyeti hakkında Isviçre Hukukunda câri olan esas

bizde de kabul edilebilir. Yani eseri olduklan teşebbüs bunların maliki saylmalıdır.

3. Mecralarn mülkiyetinin üzerinde kuruldukiarı gayrimenkulün malikine ait olduğu haller.

a) MK. m. 653 f. I e tevfikan, yalnız transit mecralara eseri oldukları teşebbüsün sahibinin mülkü nazarıyla bakılabilir. Kendisine doğrudan doğruya hizmet ettikleri gayrimenkul üzerinde bulunan mecralar, kaideten o gayrimenkulün malikinin mülkiyetindedirler. Başka bir deyimle, eğer, bir gayrimenkul üzerindeki mecra, ana şebekeden su, gaz, elektrik gibi şeyleri almak ve o gayrimenkul dahilinde istihlâk etmek üzere kurulmuşsa, bu mecranın mülkiyeti, prensip itibariyle, sınaî teşebbüse değil, o gayrimenkulün malikine ait olur. Bu esasın kabulü için muhtelif sebepler mevcuttur :

MK. m. $653 \mathrm{f}$. I in almanca metni, mecralarm kendisinden inbias ettikleri teşebbüsün sahibinin mülkü sayılabilmesi için, sarahaten bunlarin «hizmet ettikleri gayrimenkul haricinde bulunması (Leitungen... die sich ausserhalb des Grundstückes befinden, dem sie dienen) şartmı koymaktadır. Buna mukabil, mezkûr hükmün türkçe ve fransızca metinleri a... mecralar hangi arz için tesis olunmuşlar ise, onun haricinde bulunmuş olsalar bile, ... hangi sınaî teşebbüsün eseri iseler onun ... sahilinin mülkü» addedilirler (les conduites, ... même si elles se trouvent hors du fonds pour lequel elles sont établies, sont ... réputées appartenir au propriétaire de l'entreprise) şeklinde kaleme alınmışlardır; fakat bu ifade tarzı yanlış bir tefsire yol açacak mahiyettedir. Filhak:ka türkçe ve fransızca metinlerdeki «bile» (même si) tabirinden, doğrudan doğru-

(95) Derbil; a.g. e., cilt II. sh. 570. No. 7; Onar, a.g. e., sh. 1174. 
ya hizmet ettikleri gayrimenkul üzerinde bulunan mecraların mülkiyetinin evleviyetle snnaì teşebbüse ait sayılacağı istihraç olunabilir. Halbuki Medenî Kanun'un ihzarına müteallik çalışmalar böyle bir neticeye varmanın doğru olmayacağını göstermektedirler.

Isviçre'de Medenì Kanun projesinin Conseil d'Etats'da müzakeresi esnasinda (96), umumiyetle, su, gaz, elektrik abonelerinin kendi gayrimenkulleri üzerindeki tesisatı parasını ödedikleri ve binnetice bu tesisaton maliki oldukları ileri sürülmüş (97) ve bunların sınaî teşebbüsün mülkiyetine dahil sayılmaması için $\mathrm{m}$. $653 \mathrm{f}$. I e «doğrudan doğruya hizmet ettikleri gayrimenkul haricinde bulunan mecralar» kaydı ilâve edilmiştir.

Mahkeme içtihatları (98) ve doktrin (99) de, ayni mülahazalarla, abonelerin gayrimenkulleri üzerindeki mecralarm, hususuyla evlerdeki tesisatın mülkiyetinin, kaideten, abonelere ait olacağmı kabul etmektedir.

*Mecranın hizmet ettiği gayrimenkul» ibaresi acaba bizzat sinaî teşebbüsün üzerinde bulunduğu gayrimenkule de şâmil midir? Romer ve Leemann (100) bu suale müsbet cevap vermekte Zürich Kantonu Yüksek Mahkemesi de (101) aksi tezi müdafaa etmektedir. Fikrimizce bahis mevzuu ibare, bilhassa abonelerin gayrimenkulleri gözönünde tutularak konulmuştur. Eğer sinâ̂ teşebbüs üzerinde bulunduğu gayrimenkulün maliki ise veya bu gayrimenkulde bir inşaat hakkına sahipse, pek tabii olarak, kurduğu mecraları o gayrimenkul dahilindeki kismmın da maliki olur. Buna mukabil eğer teşebbüs, imalâthanesini kiraladığı bir gayrimenkulde tesis etmişse ve lehine bir inşaat hakkı da yoksa teşebbüsten çıkan mecranın mülkiyeti gayrimenkulün malikine ait bulunur.

b) MK. m. 653 f. I hükmü, transit mecraların mülkiyetinin, kendisinden inbias ettikleri teşebbüsün sahibine ve abonelerin gayrimenkulleri üzerindeki tesisatın abonelere ait olacağı hususunda sadece bir kárine koymaktadır. Mezkûr hükmün ihtiva ettiği «hilâfına bir hüküm olmadıkça ( sauf disposition contraire, wo es nicht anders geordnet ist) ibaresi onun âmir bir hüküm olmayıp, icabında aksine bir mukavele yaplabile-

(96) Bk. Bull. Stén., C. E., 1906, sh. 1271 ve müt.

(97) Zaten aradan uzun zaman geçince, mecranın tesisi masraflarını abonenin mi yoksa teşebbüsün mü ödemiş olduğunu tesbit işi çok güçleşebilir.

(98) Zürich Kantonu Yüksek Mahkemesi, BI ZR. 22 (1923). Nr. 122, sh. 233; Aargau Kantonu Yüksek Mahkemesi, SJZ. 26 (1930). sh. 85, Nr. 59.

(99) Romer, a.g. e., sh. 73; Haab, Komm., Art. 676, Nr. 13; Leemann, Art. 676, Nr. 5. Wieland, a.g. e., m. 676 (653), No. 8; Bruggmann, a.g.e., sh. 86

(100) Romer, a. g. e., sh. 73, Leemann, Komm., Art. 676, No. 4.

(101) Not 98 de zikredilen karara bk. 
ceğini sarahaten göstermektedir (102). Binaenaleyh, bir mukavele ile, transit mecralarm katettikleri gayrimenkullerin maliklerinin mülkü sayılacağı, veya bir abonenin arazisi üstündeki onun ana sebekeden istifadesini mümkün kılan mecranın snnâ̂ teşebbüse ait olacağ kararlaştırılabilir (103). Ancak böyle bir mukavelenin mevcudiyetini iddia eden taraf onu isbatla mükelleftir.

c) Nihayet, muvakkat bir müsaadeye veya sadece bir alacak hakkı doğuran mukaveleye müsteniden tesis edilen mecralar da üzerinde kuruldukları gayrimenkulün malikinin mülküne dahil olurlar (104). Bu gibi hallerde «superficies solo cedit» prensibinden inhiraf için bir sebep yoktur. Bununla beraber, eğer böylece tesis edilen mecralar, temelli kalmak maksadı olmaksızın yapılmışlarsa, MK. m. 654 hükmüne tâbi olurlar ve bunları tesis eden kimse veya teşebbüsün mülkiyetinde kalılar. Her halükârda bu mecraları kuranlara onları söküp götürme salâhiyeti tanınmalıdır.

\section{MECRALARIN ESERI OLDUKLARI TEŞEBBUSUN TEFERRUATI ADDEDILMESI.}

Bir irtifak hakkına veya mülkiyet takyidine yahut da amme hizmetini ilgilendirmeyen bir idarî tasarrufa binaen kurulan transit mecraların, kaideten, eseri oldukları teşebbüsün sahibinin mülkü sayıldıklarmı. gördük. Ancak bu mülkiyet hakku, eğer malik mecra üzerinde temlik veya terhin suretiyle tasarruf etmek imkânma sahip ise, onun için bir fayda arzeder.

Yazımızın başında da işaret ettiğimiz gibi, kanun vazı MK. m. 653 f. I hükmünü sevketmemiş olsa idi, mecraların satılması veya terhini bunların katettikleri her gayrimenkul üzerinde müstakil ve daimî bir inşaat hakkı tesisi ve bu hakkın tapuya gayrimenkul olarak kaydı suretile kabil olurdu (MK. m. 751, 632, 911). Böylece kaydedilen haklar birer gayri-

(102) Bruggmann, a.g. e., sh. 85; Romer, a. g. e., sh. 73 - 74; Haab, Komm., Art. 676, Nr. 3; Wieland, a. g. e., m. 676 (653), No. 4; Gücün, a. g. e., sh, 170, Leemann, Komm, Art. 676, No. 21.

(103) 20 Mart 1926 tarihli Ankara'da elektrik tesisat vücuda getirme ve işletme imtiyazı mukavelesinin 44 üncü maddesine göre, müstahliklere cereyan tevzii için yapılacak tesisatın, şube hattından ebniye dahilindeki emniyet kutusuna kadar olan kısmı şirket malı addolunup bunun bedeli hane sahibi veya müsteciri tarafundan verilecektir. Ankara Asliye Mahkemesi 2. Ticaret Dairesi 2/12/1948 de bu maddeye binaen bir karar ittihaz eylemistir. (E. 312/K. 133).

(104) Haab, Komm., Art. 676, Nr. 7; Bruggmann. a. g. e., sh. 77; Wieland, a. g. e., $m$; 676 (653), No. 4 . 
menkul gibi temlik veya terhin (MK. m. 770; Tapu Sicilli Nizamnamesi, m. $41-42,45)$ edilebilirlerdi.

Fakat_bu usul büyük güçlükler ve masraflar doğuracağı gibi (105) teşebbüsle mecralarn teşkil ettiği iktisadî vahdetin temenniye şayan olmayan bir parçalanmasın icap ettirecekti (106).

tşte bu mahzurları önlemek ve teşebbüs üzerindeki tasarrufun mecralara da şamil olmasını temin etmek maksadıyla, kanun vazı, mecralarn eseri olduklan teşebbüsün teferruatı addedilmesi suretinde bir fiksiyon kabul etmiștir (107).

1. Mecralarn teşebbiisin teferruatı addedilmesinin șartları.

Mecraların, teşebbüsün teferruatı addedilebilmesi için şu şartların mevcudiyeti gerekir :

a) Bahis mevzuu mecralar, mülkiyeti teşebbüs sahibine ait bulunan transit mecralar olmalıdır (108). Teşebbüsün üzerinde imalâthanesini kurduğu kendisine ait gayrimenkul dahilindeki mecralar zaten bu gayrimenkulün mütemmim cüzüleri olup teferruat saylmalarna hacet yoktur. Teşebbüsün istihsal veya tevzi ettiği kuvvet ve maddeleri istihlâk eden abonelerin arazileri üzerindeki tesisat, bir alacak hakkına binaen yerleştirilen veya bir mukavele ile mülkiyetinin üzerinden geçtiği gayrimenkulün malikine ait olacağı kararlaştırılan mecralar teferruat hükmünde tutulamazlar.

b) Teşebbüs mecranın naklettiği kuvvet ve maddeleri istihsal eden bir ana teşebbüs olabileceği gibi, bu madde ve kuvvetleri başkasından satm alp sadece tevzi eden ikinci derecede bir teşebbüs de olabilir (109).

Münferit bir gayrimenkulün ihtiyaçları için tesis edilen cüzi ehemmiyetteki mecraların (meselâ bir su harkının, veya kirli suları boşaltan bir mecranın), ortada bir teşebbüs bulunmasa dahi, kıyasen o gayrimenkulün teferruatı saylmasinda bir mahzur yoktur. Zaten böyle bir mecra umumiyetle bir gayrimenkul irtifak hakkına veya komşuluk münasebetlerine müsteniden tesis edildiğginden hâkim gayrimenkulün temliki halinde yeni malik mecraya sahip olur ve onu idame ettirebilir.

(105) Filhakika bu inşaat hak!arının evvelâ her bir hâdim gayrimenkulün sahifesine ayrı ayrı tescil ediimeleri lâzımđı. Sonra da gayrimenkul olarak kaydedilirken ayni mintakada olanları müşterek bir sahifeye kaydetmek mümkünse de (Tapu Sicilıi Nizamnamesi, m. 6), bu imkân, mecralar ekseriya bir çok mintakalara yayıldiklarından büyük bir kolaylik temin etmeyecektir.

(106) Haab, Komm., Art. 676, Nr. 12. Bk. yukarida not 2.

(107) Romer, a.g. e., sh. 75; Leemann, Komm. Art. 676, No. 24.

(108) Haab, Komm. Art. 676, Nr. 13; Romer, a. g. e., sh. 73

109) Bruggmann, a. g. e., sh. 86; Leemann, Komm., Art. 676, Nr. 7. 
Bern Kantonu Istinaf Mahkemesi, bir şehir kanalizasyonunun muhtelif kolları hakkında MK. m. 653 f. I deki teferruat prensibinin tatbik edilemeyeceğine hükmetmiştir (110). Mahkemenin kanaatınca, ne kanalizasyondan istifade eden evler ne de bizzat kanalizasyonun heyeti umumiyesi bir teşebbüs saylabilir. Federal Mahkeme ise, yakın bir zamanda, kanalizasyonun bizzat kendisinin teşebbüs addedilmesi gerektiği içtiha. dinda bulunmuştur (111).

c) Teşebbüs sahibi, teşebbüsün kurulduğu arazinin maliki veya bu arazi üzerinde tesis ve tapu sicilline gayrimenkul olarak kaydedilen müstakil ve daimî bir hakkın (kaynak hakkı, inşáat hakkı, su imtiyazı: Tapu Sicilli Nizamnamesi, m. 8-9) sahibi olmalıdır. Ancak bu suretle, teşebbüsün başkalarının arazilerinden geçen mecralara müteallik mülkiyet hakkı ve yine teşebbüsün kendi gayrimenkulü üzerindeki mülkiyet hakkı sübjektif - aynî bir bağla (eine subjektiv - dingliche Verbindung) bağlanabilir (112). Eğger teşebbüsün kendisine ait bir gayrimenkulü yoksa, teşebbüs sahibi geçireceği mecralar için birer gayrimenkul. irtifak hakkı tesis edemez; şahsî irtifak haklarına binaen bu mecraların maliki olsa dahi ortada hâkim bir gayrimenkul yoktur ki onun üzerindeki tasarruflar mecralara da şamil sayllabilsin. Binaenaleyh, eğer mecralar bir irtifak hakkına müsteniden tesis ediliyorlarsa, teferruat prensibinin tatbik edilebilmesi için, bu irtifak hakkı gayrimenkule taallûk eder mahiyette olmalıdır (113). İrtifak hakkının ortadan kalkması veya şahsî bir irtifak hakkına tahvil edilmesi neticesinde mecra mülkiyeti ile teşebbüsün gayrimenkulünün mülkiyeti arasındaki sübjektif - aynî bağ çözülür ve mecra teşebbüsün teferruatı olmaktan çıkar.

2. Mecraların tesebbüsün teferruatı addedilmesinin neticeleri.

Mecraların eseri oldukları teşebbüsün teferruatı sayılması, esas itibarıyla, teşebbüs üzerindeki tasarrufların bunlara da şamil olmasını temin eder. Filhakika MK. m. 621 f. I e göre: "Bir şeye ait yapılacak temlikî tasarmıflarda o şeyin istisna olunmayan teferruatı dahil olur.» Ancak mecraların teşebbüsün teferruatı sayılması yukarıda saydığımız şartların tahakkukuna bağlı olduğundan umumiyetle şeylerin teferruatına ait kaideler burada kıyasen, mezkûr şartların müsaadesi nisbetinde, tatbik sahası bulurlar :

(110) ZbJV. 72 (1936), sh. 405.

(111) RO 75 II 116 yahut Jd T, 1949, p. 627, cons. 2, «Einwohnergemeinde Bern c. Fischereipachtvereinigung Bern».

(112) Haab, Komm., Art. 676, Nr. 15 - 16; Leemann, Komm., Art. 676, Nr. 24.

(113) Bk. Yukarida IV, 1, d. 
a) Teşebbüsün kendi gayrimenkulünü ferağı, mecralarm mülkiyeti ile bu gayrimenkulün mülkiyeti sübjektif - aynî bir bağla bağlı bulunduğu müddetçe (114), mutlak surette mecralara da şamil olur. Teşebbüsün gayrimenkulünün feră̆ edilmesine rağmen, mecraların tamamının veya bir kısmınjn müteşebbisin mülkiyetinde kalabilmesi için, MK. m. $621 \mathrm{f}$. I in müsaade ettiği veçhile, mukavelede bu hususta bir «istisna» kabul edilmesi kâfi gelmez (115); bunun için evvelâ mülkiyet hakları arasındaki sübjektif - aynî rabıta çözülmek làzımdır. Eğer mecra, bir gayrimenkul irtifak hakkına binaen kurulmuşsa, bu, şahsî bir irtifak hakkına tahvil edilmelidir. Böyle bir tahvil için de hâdim gayrimenkul malikinin rızası ve, mecra açlkta olsa dahi, irtifak hakkının tescili lâzımdır.

b) MK. m. $621 \mathrm{f}$. I deki esas, teşebbüsün terhini halinde daha iyi tatbik edilmeğe müsaittir. Rehin mukavelesinde hilâfı şart edilmedikçe, teşebbüsün terhini onun teferruatı sayılan mecralara da şamil olur. Taraflar mukavelede rehnin yalnız teşebbüsün gayrimenkulüne veya bu gayrimenkulle birlikte mecra şebekesinin bir kısmına münhasır olacağın tasrih edebilirler (116). Bu suretle mecralarm tamammin veya bir kısminum rehnin mevzuundan hariç tutulduğu, hüsnüniyetli üçüncü şahısların mutazarrır olmamaları için, tapu sicilline tescil ve bir ipotekli borç veya irat senedi varsa onun üzerine șerh edilmelidir. Teșebbüsün terhininden sonra da alacaklınm mecraların tamamı veya bir kısmı üzerindeki rehin hakkından feragati mümkündür.

c) Mecralar teferruat addedilmekle gayrimenkul olmak vasfını kaybetmezler (117). Bunun böyle olduğunu, tesislerini mümkün kılan irtifak hakkının veya mülkiyet takyidinin ortadan kalkmasıyla yeniden üzerinde bulundukları gayrimenkulün mütemmim cüz’ü olmaları açıça gösterir. Halbuki umumiyetle şeylerin teferruatı menkullerdir (MK. m. 621 f. II). Binaenaleyh asıl șeyin maliki bu sonuncu neviden teferruat üzerinde asıl şeyden müstakil olarak tasarruf edebilir. Halbuki mecralara ve teşebbüsün gayrimenkulüne ait mülkiyet hakları sübjektif - aynî bağla bağlı bulundukları müddetçe mecralar teşebbüsten ayrı olarak ne temlik ne de terhin edilebilirler.

(114) Mecra bir gayrimenkul irtifak hakkına binaen veya teşebbüse ait gay. rimenkulün sahibinin komșuluk münasebetlerini ileri sürmesi suretiyle tesis edilmişse böyle bir sübjektif - aynî bağ mevcuttur.

(115) Haab, Komm., Art. 676, Nr. 17; Homberger - Marti, FJS, No. 428, sh. 6. Aksi fikirde : Hirs, a.g. e., sh. 58

(116) Haab, Komm., Art. 676, Nr. 18

(117) Federal Mahkeme'nin "Bernische Krafwerke c. Commune de Wimmis» davasindaki kararı : RO 48 I 449 yahut Jd T, 1923, sh. 326 ve müt.; Wieland, m. 676 (653), No. 2; Leemann, Komm. Art. 676, Nr. 24 
d) Türk hukukunda, umumiyetle teferruatın asıl şeyden müstakil. len haczinin caiz olmadığ kabul edilmektedir (118). Ayni esas teferruat sayılan mecralar için de varittir. Yani bunlar teşebbüsten ayn olarak hacze tabi tutulamazlar.

Isviçre'de bir gayrimenkulün teferruatı, borçlu ve tapu sicilline göre alâkalı bütün şahıslar kabul ederlerse, müstakillen haczedilebilir (Federal Mahkeme’nin 23 Nisan 1920 tarihli egayrimenkullerin cebrî paraya çevrilmesi hakkındaki» talimatnamesi, m. 12). Bu hükmün mecraların tatbiki doğru olmaz.

e) Umumiyetle teferruat hakkındaki MK. m. 777 f. II hükmü de teferruat sayılan mecralara kabili tatbik değildir (119). Binaenaleyh rehin senedinde bazı şeylerin mecra olarak gösterilmesi ve bunun tapu sicilline șerh verilmesi hukukan bir klymet ifade etmez; böyle bir şerh vasitasıyla MK. m. 653 ün şartları tahakkuk etmeksizin bir mecraya teşebbüsün teferruatı vasfı izafe edilemez (120). Buna mukabil, tapu sicilline teşebbüsün gayrimenkulünün evsafına tahsis edilen haneye mecraların ehlivukufça takdir edilen kıymetini şerh vermekte bir beis yoktur (121).

(Devamı gelecek sayıda)

(118) Mustafa Reşit Belgesay : İcra ve Iflas Kanunu șerhi, II. bas1, İstanbui 1948, cilt I, No. 423.

(119) Wieland, a.g. e., m. 676 (653), No. 2 d; Haab, Komm., Art. 676, Nr. 20; Leemann, Komm. Art. 676, Nr. 27.

(120) Zürich Yüksek Mahkemesi, BIZR, XX (1921), No. 2, sh. 2.

(121) St. Gallen Hükûmet Surası'na göre açıkta olan mecraların kıymetine müteallik böyle bir şerh, takdir edilen gayrimenkul kıymetinin ve o gayrimenkulï rehinle takyid haddinin (MK. m. 813 ve 818) yükseltilmesini icap ettirmez (SJZ, 14 (1917/1918), sh. 123, Nr. 91) 